\title{
Correction to: The Connection Between the Body and the Environment: a Changing View
}

\author{
Meloni, Maurizio (2019) Impressionable Biologies: from the Archae- \\ ology of Plasticity to the Sociology of Epigenetics. Routledge, New \\ York and London. ISBN: 978-1-138-04941-3, 216 Pages, Price: \$ 27.50 \\ (paperback)
}

\section{Birgitta Mc Ewen ${ }^{1}$}

Accepted: 14 January 2021/ Published online: 23 March 2021

(C) The Author(s) 2021

\section{Correction to: Science \& Education (2020) 29:1093-1096}

https://doi.org/10.1007/s11191-020-00134-6

The article The Connection Between the Body and the Environment: a Changing View Meloni, Maurizio (2019) Impressionable Biologies: from the Archaeology of Plasticity to the Sociology of Epigenetics. Routledge, New York and London. ISBN: 978-1-138-04941-3, 216 Pages, Price: \$ 27.50 (paperback), written by Birgitta Mc Ewen was originally published Online First without Open Access. After publication in volume 29, issue 4, pages 1093-1096, the author decided to opt for Open Choice and to make the article an Open Access publication. Therefore, the copyright of the article has been changed to (C) The Author(s) 2021 and the article is forthwith distributed under the terms of the Creative Commons Attribution 4.0 International License, which permits use, sharing, adaptation, distribution and reproduction in any medium or format, as long as you give appropriate credit to the original author(s) and the source, provide a link to the Creative Commons licence, and indicate if changes were made. The images or other third party material in this article are included in the article's Creative Commons licence, unless indicated otherwise in a credit line to the material. If material is not included in the article's Creative Commons licence and your intended use is

The online version of the original article can be found at https://doi.org/10.1007/s11191-020-00134-6

Birgitta Mc Ewen

birgitta.mcewen@kau.se

1 Department of Health Sciences, Karlstad University, Karlstad, Sweden 
not permitted by statutory regulation or exceeds the permitted use, you will need to obtain permission directly from the copyright holder. To view a copy of this licence, visit http:// creativecommons.org/licenses/by/4.0.

Open Access This article is licensed under a Creative Commons Attribution 4.0 International License, which permits use, sharing, adaptation, distribution and reproduction in any medium or format, as long as you give appropriate credit to the original author(s) and the source, provide a link to the Creative Commons licence, and indicate if changes were made. The images or other third party material in this article are included in the article's Creative Commons licence, unless indicated otherwise in a credit line to the material. If material is not included in the article's Creative Commons licence and your intended use is not permitted by statutory regulation or exceeds the permitted use, you will need to obtain permission directly from the copyright holder. To view a copy of this licence, visit http://creativecommons.org/licenses/by/4.0/.

Publisher's Note Springer Nature remains neutral with regard to jurisdictional claims in published maps and institutional affiliations. 